\title{
POLA ASUH ANAK OLEH IBU USIA DINI
}

\author{
Oleh: \\ Enggal Wildan Prabowo, Ishartono, Dan Meilanny Budiarti
}

Email :

Enggal_metro@yahoo.com; ishartono_kesos@yahoo.com; meilannybudiarti13@gmail.com

\begin{abstract}
ABSTRAK
Penelitian ini memfokuskan pada pola asuh anak oleh ibu yang masih berusia dini dengan studi kasus yang terletak di desa Lengkongbarang. Dalam tulisan ini dijelaskan bagaimana pola pengasuhan yang dilakukan oleh Ibu yang masih berusia dini. Objek penelitian ini adalah bagaimana pola asuh anak oleh Ibu yang masih berusia dini atau remaja di Desa Lengkongbarang, dengan menggunakan metode deskriptif. Data yang digunakan dalam penelitian ini terdiri dari data primer dan data sekunder yang berasal dari dokumen-dokumen, arsip, buku-buku, atau pun jurnal-jurnal ilmiah. Penelitian ini menjelaskan fenomena yang cukup banyak terjadi di lingkungan masyarakat yaitu menganai pola asuh anak oleh Ibu yang masih berusia dini. Sesuai dengan sifat dari objek penelitian ini, maka pendekatan penelitian ini merupakan penelitian kualitatif. Penelitian ini menunjukkan bagaimana Ibu yang masih berusia dini, atau masih berusia remaja dalam memenuhi kebutuhan dasar anaknya. Dalam hal ini, masalah yang terjadi adalah apabila kebutuhan dasar anak tidak dapat dipenuhi oleh orangtua, terutama oleh Ibu yang masih berusia dini atau remaja. Masalah tersebut merupakan masalah yang harus segera diselesaikan agar tidak menimbulkan masalah lain pada anak. Masa anakanak adalah masa dimana terdapat usia emas atau yang sangat memengaruhi pertumbuhan dan perkembangan anak. Untuk itulah kebutuhan dasar anak harus dipenuhi dengan baik, agar tidak menggangu masa-masa pertumbuhan maupun perkembangan anak. Namun, pada kenyataannya hal tersebut dapat terhambat apabila Ibu yang masih berusia dini tidak dapat memberikan kebutuhan dasar anak secara maksimal dikarenakan usia Ibu yang masih dini. Hal ini juga dapat membuat keadaan anak cukup terancam karena cukup banyak anak yang ditelantarkan oleh Ibu yang masih berusia dini.
\end{abstract}

Kata Kunci : Pola asuh, Orangtua (Ibu Usia Dini), Pekerjaan Sosial, Pernikahan Usia Dini

\section{ABSTRACT}

This research focuses on parenting children by the mother who was early with a case study in the village of Lengkongbarang. In this writing explained how parenting patterns conducted by the mother who was early. The object of the research is how parenting children by the mother who was early or teen in the village of Lengkongbarang, using a descriptive method. The data used in this study consists of primary and secondary data is data that is derived from the documents, archives, books, or scientific journals. This study describes the phenomenon that is quite a lot going on in the community environment of parenting children by the mother who was early. In accordance with the nature of the object of this research, the research approach is qualitative research. This research shows how the Mother was an early teenager, or still in meeting the basic needs of their children. In this case, a problem that occurs is when the child's basic needs could not be met by a parent, especially a Mother by age or early teens. The problem is a problem that must be resolved soon so as not to give rise to 
other problems in children. The children are a time where there is a golden age or golden age, which strongly influenced the growth and development of the child. For that is the child's basic needs must be met as well, so as not to interfere with the growth and development of the child. However, in reality it can be hampered if the mother who was early unable to provide the basic needs of children to the maximum because of the age of the mother who is still early. It can also make things quite threatened children because quite a lot of children who are abandoned (neglect) by the mother who was early.

Keywords: parenting, parent (mother of early childhood), Social Work, Early Marriage

\section{PENDAHULUAN}

Studi yang pernah dilakukan United Nations Children's Fund (UNICEF), fenomena kawin di usia dini (early marriage) masih sering ditemukan pada masyarakat yang berada di wilayah Timur Tengah dan Asia Selatan dan pada beberapa kelompok masyarakat di Sub Sahara Afrika. Di Asia Selatan terdapat sebesar 9,7 juta anak perempuan atau $48 \%$ menikah pada umur dibawah usia 18 tahun, sementara di Afrika terdapat sebesar $42 \%$ dan Amerika Latin terdapat sebesar 29\%.

Di Indonesia, angka statistik yang menunjukkan pernikahan usia dini dengan pengantin berumur dibawah usia 16 tahun secara nasional mencapai lebih dari seperempat, bahkan di beberapa daerah, sepertiga dari pernikahan yang terjadi tepatnya berada di Jawa Timur 39,43\%, Kalimantan Selatan 35,48\%, Jambi 30,63\% dan Jawa Barat $36 \%$ (Singgih B, Setyawan, 2007).

Untuk masyarakat yang berada di daerah pedesaan, perkawinan usia dini terjadi terutama pada golongan ekonomi menengah kebawah, sementara untuk masyarakat yang berada di daerah perkotaan, perkawinan usia dini biasanya terjadi karena "kecelakaan" (married by accident) yang diakibatkan karena pergaulan bebas oleh remaja.

Perkawinan yang terjadi di usia dini sebenarnya memberi risiko yang lebih besar pada remaja perempuan khususnya pada kesehatan reproduksinya. Perkawinan usia dini juga akan memengaruhi pengetahuan dalam memberikan pola asuh anak yang baik dan benar. Aspek sosial budaya masyarakat memberi pengaruh yang cukup besar terhadap terjadinya perkawinan atau pernikahan khususnya dalam pernikahan usia dini.

Pengetahuan kaum perempuan khususnya oleh remaja perempuan yang rendah mengenai kesehatan reproduksi, dukungan keluarga sehubungan dengan peran sosial budaya, masalah kebutuhan ekonomi, seks bebas pada remaja, dan kebijakan pemerintah dalam perpanjangan usia perkawinan merupakan faktor yang menyebabkan terjadinya pernikahan di usia dini.

Dengan banyaknya pernikahan usia dini yang dilakukan oleh remaja perempuan tersebut, maka ketika usia remaja tersebut telah memiliki anak, mampukah Ibu usia dini tersebut memenuhi kebutuhan dasar anak. Terkait dengan hal tersebut, dengan keterbatasan pengetahuan yang dimiliki oleh Ibu usia dini tersebut, bagaimana Ibu usia dini tersebut melakukan pola suh terhadap anak. Apabila Ibu usia dini tersebut tidak mampu memenuhi kebutuhan dasar anak, maka akan menjadi masalah bagi anak yang dilahirkan dari Ibu usia dini tersebut.

Topik penelitian ini dipilih dan dianggap penting karena selama ini penelitian terkait dengan pernikahan usia dini masih sangat terbatas dan lebih banyak kepada analisis kajian kesehatan ataupun kajian hukum dan agama.

Tujuan yang ingin dicapai dari penelitian ini adalah sebagai upaya untuk mencegah terjadinya pernikahan usia dini dikalangan remaja, memberikan pengetahuan mengenai pola asuh anak yang baik dan benar serta upaya dalam pengendalian tingkat kelahiran dalam kependudukan. 
Berdasarkan hal tersebut, penelitian tentang pola asuh anak oleh Ibu usia dini perlu dilaksanakan.

\section{PEMBAHASAN}

\section{Pernikahan Usia Dini}

Pernikahan usia dini adalah pernikahan yang dilakukan pada usia yang melanggar aturan Undang-Undang Perkawinan yaitu perempuan kurang dari 16 tahun, dan laki-laki kurang dari 19 tahun. Pernikahan pada usia dini merupakan bentuk kegiatan yang sudah dilaksanakan oleh masyarakat, dipengaruhi oleh banyak faktor dan melibatkan berbagai faktor perilaku.

Pernikahan usia dini sebagai bentuk perilaku yang dapat dikatakan membudaya dikalangan masyarakat Indonesia. Artinya bahwa batasan individu dalam meninjau kesiapan dan kematangan usia individu bukan menjadi penghalang bagi seseorang untuk tetap melangsungkan pernikahan.

Pernikahan usia dini dapat terjadi dikarenakan adanya dorongan rasa kemandirian dari remaja perempuan untuk melepaskan diri dari pengaruh orangtua. Selain itu, pernikahan usia dini juga terjadi karena mengandung unsur perbaikan sosial ekonomi keluarga karena dengan cara menikah, seseorang remaja perempuan akan memeroleh perbaikan ekonomi keluarganya jika menikah dengan laki-laki yang mapan dalam segi ekonomi.

Pernikahan usia dini yang disebabkan karena alasan membantu pemenuhan kebutuhan ekonomi keluarga, berhubungan dengan rendahnya tingkat ekonomi keluarga dimana orangtua tidak memiliki kemampuan untuk memenuhi kebutuhan keluarga sehingga orangtua memilih untuk mempercepat pernikahan anaknya terlebih lagi bagi anak perempuan sehingga dapat membantu pemenuhan kebutuhan keluarga.

Perkawinan usia dini berhubungan dengan kemiskinan, pertukaran ekonomi saat perkawinan dan pendidikan rendah.
Perkawinan ini berdampak pada kehidupan sosial gadis remaja. kemampuan membuat keputusan, kesehatan dan perilaku seksual dan reproduksi, serta kemampuan bernegosisasi dengan pasangan dan keluarga mengenai perilaku sehat.

Perkawinan usia muda yang terdorong oleh alasan kernandirian dan terbebas dari pengaruh dari orang tua berhubungan dengan sikap yang terbangun antara anak dan oraug tua. Hal ini berhubungan dengan cara orangtua menerapkan pola pengasuhan kepada anak.

\section{Faktor Penyebab Pernikahan Usia Dini}

Pernikahan usia dini yang terjadi di kalangan masyarakat diawali dengan adanya persetujuan antara orangtua laki-laki maupun perempuan. Kesepakatan ini bagi orangtua lebih didasarkan atas pemahaman orangtua kepada menantunya akan dapat membantu pelaksanaan segala aktivitas keluarga termasuk dalam upaya perbaikan ekonomi keluarga.

Pendidikan atau pengetahuan yang rendah tentang kesehatan reproduksi memicu terjadinya pernikahan usia dini. Hal ini akan sangat berbahaya karena pada umumnya usia remaja merupakan usia yang belum cukup matang. Pemahaman ini berhubungan dengan kemampuan seorang remaja perempuan mengalami kehamilan dan melahirkan bayi yang sehat, menghindari terjadinya keguguran, menghindari penyakit yang berhubungan dengan kandungan, dan harus terjaga melalui upaya perbaikan gizi selama kehamilan serta tidak memiliki perilaku bergonta-ganti pasangan.

Orangtua memiliki peran yang lebih besar baik dalam pelaksanaan pernikahan usia dini anaknya maupun pada upaya penundaan usia perkawinan anak. Orangtua memiliki keterbatasan pemahaman khususnya tentang kesehatan reproduksi dan hak anak, kecenderungan yang terjadi adalah menikahkan anak pada usia dini atau usia remaja. Begitupula pada keluarga yang tidak memiliki hubungan harmonis dalam keluarga 
(broken home) akan berdampak pada perilaku seks bebas anak dan dapat berujung pada perkawinan yang berlangsung cepat/pada usia dini.

Peran orangtua dalam menentukan perkawinan anak dipengaruhi oleh faktor sosial ekonomi keluarga, tingkat pendidikan keluarga, kepercayaan dan adat istiadat yang berlaku dalam keluarga dalam menghadapi masalah remaja.

\section{Orangtua}

Menurut Soegarda dalam (Bariroh, 2006 : 5) Yang dimaksud dengan orangtua adalah pendidik atas dasar hubungan darah. Orangtua memiliki fungsi serta peran sebagai pelindung anggota keluarga.

Fungsi dan peran orangtua menurut Arifin dalam (Bariroh, 2006 : 5) adalah sebagai pelindung setiap anggota keluarga. Keluarga adalah sebagai persekutuan hidup terkecil dari masyarakat negara yang luas. Pangkal ketentraman dan kedamaian hidup terletak dalam keluarga mengingat pentingnya hidup keluarga itu maka Islam memandang keluarga bukan hanya sebagai persekutuan hidup terkecil saja, tetapi lebih dari itu yakni sebagai lembaga hidup manusia yang dapat memberi kemungkinan celaka dan bahagianya anggotaanggota keluarga tersebut dunia dan akhirat.

\section{Pola Asuh Orangtua}

Peranan ibu dalam pola pengasuhan anak berupa sikap dan praktek pengasuhan ibu dalam kedekatannya dengan anak, merawat, cara memberi makan, serta kasih sayang. Pengasuhan anak adalah suatu fungsi penting pada berbagai kelompok sosial dan kelompok budaya. Peranan ibu dalam pola pengasuhan anak juga meliputi pemenuhan kebutuhan dasar anak seperti pemberian makan, mandi, menyediakan dan memakai pakaian buat anak. Termasuk didalamnya adalah monitoring kesehatan anak, menyediakan obat, dan membawanya ke petugas kesehatan profesional (O’Connel 1992 dan Bahar 2002).
Sesuai dengan yang diajukan oleh Mosley dan Chen 1988 dalam (Bahar, 2002) pengasuhan anak meliputi aktivitas perawatan terkait gizi atau penyiapan makanan dan menyusui, pencegahan dan pengobatan penyakit, memandikan anak, membersihkan pakaian anak, membersihkan rumah. Pola asuh terhadap anak merupakan hal yang sangat penting karena akan memengaruhi proses tumbuh kembang balita. Pola pengasuhan anak berkaitan erat dengan keadaan ibu terutama kesehatan, pendidikan, pengetahuan, sikap dan praktik tentang pengasuhan anak Suharsih dalam (Anas, 2013). Dalam berbagai penelitian menunjukkan bahwa kepribadian orangtua sangat menentukan pola interaksi ibu dan anak. Pengaruh struktur dan watak ibu yang mengasuh anak balita mempunyai efek yang sangat besar dalam hubungan ibu dan anak.

Kerangka konseptual yang dikemukan oleh UNICEF (1997) menekankan bahwa tiga komponen makanan, kesehatan dan asuhan merupakan faktor-faktor yang berperan dalam menunjang pertumbuhan dan perkembangan anak yang optimal. Engle et all (1997) mengungkapkan bahwa pola asuh dimanifestasikan dalam 6 hal, yaitu :

1. Perhatian atau dukungan terhadap wanita seperti pemberian waktu istirahat yang tepat atau peningkatan asupan makanan selama hamil

2. Pemberian ASI dan makanan pendamping anak

3. Rangsangan psikososial terhadap anak dan dukungan untuk perkembangan mereka

4. Persiapan dan penyimpanan makanan

5. Praktek kebersihan/hygiene sanitasi lingkungan

6. Perawatan keluarga dalam keadaan sakit meliputi praktek kesehatan di rumah dan pola pencarian pelayanan kesehatan.

Asuh Makan 
Asuh makan adalah cara makan seseorang atau sekelompok orang dalam memilih makanan dan memakannya sebagai tanggapan terhadap pengaruh fisiologi, psikologi budaya dan sosial (Waryana dalam Anas 2013). Untuk kebutuhan pangan/gizi, ibu menyiapkan diri sejak prenatal (sebelum kelahiran) dalam mengatur dietnya selama kehamilan, masa neonatal (baru melahirkan) berupa pemberian ASI, menyiapkan makanan tambahan berupa makanan padat yang lebih bervariasi bahannya atau makanan yang diperkaya, dan dukungan emosional untuk anak. Status sakit, pola aktivitas, asupan gizi rendah, frekuensi konsepsi terkait pertumbuhan anak melalui status gizi ibu (pengasuhan makanan anak terdiri atas hal yang berhubungan dengan menyusui, dan pemberian makanan selain ASI untuk anak).

\section{Asuh Diri}

Sulistijani dalam (Anas, 2013) mengatakan bahwa lingkungan yang sehat perlu diupayakan dan dibiasakan tetapi tidak dilakukan dalam sekaligus, harus perlahanlahan dan terus menerus. Lingkungan sehat terkait dengan keadaan bersih, rapi dan teratur. Oleh karena itu, anak perlu dilatih untuk mengembangkan sifat-sifat sehat seperti berikut : 1. Mandi (2 kali sehari), 2. Cuci tangan sebelum dan sesudah makan, 3. Makan teratur (3 kali sehari), 4. Menyikat gigi sebelum tidur dan 5. Buang air kecil atau besar pada tempatnya/WC.

Anwar dalam (Anas 2013) menyatakan asuh diri meliputi perilaku ibu memelihara kebersihan rumah dan lingkungan sekitarnya, hygiene kebersihan makanan, dan sanitasi lingkungan. Pemberian nutrisi tanpa memperhatikan kebersihan akan meningkatkan risiko balita mengalami infeksi, seperti diare. Hasil penelitian Widodo dalam (Anas, 2013) mengungkapkan akibat rendahnya sanitasi dan hygiene pada pemberian MP ASI memungkinkan terjadinya kontaminasi oleh mikroba, sehingga meningkatkan risiko atau infeksi lain pada balita. Sumber infeksi lain adalah permainan dan lingkungan yang kotor.

\section{Asuh Kesehatan}

Status kesehatan merupakan salah satu aspek pola asuh yang dapat mempengaruhi status gizi balita kearah yang lebih baik. Balita merupakan kelompok yang rentan terhadap penyakit. Hal ini berkaitan dengan interaksi terhadap sarana dan prasarana yang ada di lingkungan rumah tangga dan lingkungan sekelilingnya. Menurut Budi dalam (Anas, 2013) menyatakan bahwa jenis sakit yang dialami, frekuensi sakit, lama sakit yang diderita sangat mempengaruhi kesehatan dan status gizi balita.

Status kesehatan anak dapat ditempuh dengan cara memperhatikan keadaan gizi, kelengkapan imunisasinya, kebersihan diri anak dan lingkungan dimana dia berada serta upaya ibu dalam mencari pengobatan jika anak tersebut sakit (Zeitlin dalam Anas, 2013).

Perilaku ibu dalam menghadapi anak balita yang sakit dan pemantauan kesehatan terprogram adalah pola pengasuhan kesehatan yang sangat mempengaruhi status gizi balita. Balita yang mendapatkan imunisasi, lebih rendah mengalami resiko penyakit. Anak balita yang dipantau status gizinya di Posyandu melalui kegitan penimbangan akan lebih mudah mendapatkan informasi akan adanya gangguan status gizi pada balita. Sakit yang lama akan mempengaruhi nafsu makan balita yang berakibat pada rendahnya asupan gizi.

Dengan demikian bagaimana pola asuh yang diberikan oleh orangtua kepada anaknya sangat berpengaruh terhadap perkembangan anak, apabila kebutuhan dasar (basic needs) anak dalam usia emasnya (golden ages) tidak terpenuhi, maka akan sangat berdampak buruk bagi anak tersebut baik saat ia masih anak-anak bahkan hingga dewasa nanti. Untuk itulah mengapa pola pengasuhan oleh orangtua usia dini harus dilakukan dengan baik dan benar agar kebutuhan anak terpenuhi dan agar 
pertumbuhan serta perkembangan anak berjalan sesuai dengan semestinya.

\section{Pekerjaan Sosial}

Pekerjaan sosial adalah sebuah profesi yang dikembangkan sebagai komponen praktis dari kesejahteraan sosial, yang menerapkan hasilhasil kajian kesejahteraan sosial tentang kehidupan sosial manusia. Secara sederhana, pekerjaan sosial dapat didefinisikan sebagai suatu bidang keahlian yang memiliki kewenangan untuk melaksanakan berbagai upaya guna meningkatkan kemampuan orang dalam melaksanakan fungsi-fungsi sosialnya melalui proses interaksi; agar dapat menyesuaikan diri dengan situasi kehidupannya secara memuaskan (Wibhawa dkk dalam Irham. $2010: 42$ )

Selain itu, terdapat pula beberapa pengertian pekerjaan sosial, diantaranya menurut Max Siporin (Wibhawa dkk. dalam Irham 2010 : 43) mendefinisikan ; "Social work is defined as a sosial institutional method for helping people to prevent and resolve their social problem, to restore and enhance their social functioning." "Pekerjaan sosial didefinisikan sebagai metode institusi sosial untuk membantu orang-orang guna mencegah dan menyelesaikan masalah sosial dengan cara memperbaiki dan meningkatkan keberfungsian sosialnya."

Selanjutnya adalah definisi pekerjaan sosial menurut Charles Zastrow dalam Wibhawa dalam Irham (2010 : 45) menjelaskan definisi pekerjaan sosial sebagai berikut : "Social work is the profesional activity of helping individuals, groups, or communities to enhance or restre their capacity for social functioning and to create societal conditions favorable to their goals." "Pekerjaan sosial adalah aktivitas profesional untuk membantu individu, kelompok atau komunitas guna meningkatkan atau memperbaiki kapasitas tujuan-tujuannya."

Berdasarkan dari uraian pengertian-pengertian tersebut, dapat disimpulkan bahwa pekerjaan sosial memfokuskan pekerjaannya pada upaya untuk meningkatkan keberfungsian sosial dari individu, keluarga, kelompok, maupun masyarakat.

Permasalahannya adalah orangtua usia dini yang dapat dikategorikan ke dalam masa remaja adalah usia yang belum memiliki kedewasaan sikap dan perbuatan. Selain itu, sikap dan perbuatan yang dilakukan oleh remaja cenderung labil atau berubah-ubah sesuai dengan apa yang mereka inginkan. Dengan labilnya sikap yang dimiliki oleh remaja, akan lebih riskan apabila pada usia remaja telah memutuskan untuk menikah dan berkeluarga (memiliki anak). Hal tersebut akan berdampak pada keadaan anak dari orangtua (ibu) usia dini. Karena pola asuh yang diberikan oleh orangtua sangat berpengaruh besar terhadap tumbuh kembang anak disamping pemenuhan kebutuhan kepada anak pun menjadi faktor penting dalam upaya mengasuh anak hingga dewasa.

\section{Teknik dan Praktik Pekerjaan Sosial}

Dalam praktik pekerjaan sosial dikenal dengan adanya dua setting yaitu primary setting dan secondary setting, keduanya merupakan lapangan praktik pekerja sosial dimana profesi pekerjaan sosial memiliki kedudukan yang sentral/utama dan profesi lain bertindak sebagai penunjang, contohnya dalam lembaga pelayanan sosial. Secondary setting adalah pekerjaan sosial dalam organisasi atau bidang praktik yang berfungsi menunjang kegiatan profesi lainnya.

Dalam kaitannya dengan penelitian ini yaitu mengenai pola asuh anak oleh ibu (orangtua) usia dini, maka dalam pemberian konteks pelayanan sosial bagi orangtua, intervensi yang dapat dilakukan oleh pekerja sosial dalam menangani hal ini adalah menggunakan metode bimbingan sosial perseorangan (social casework). Dalam social casework pendekatan dilakukan secara individual untuk mengetahui dan menggali informasi dari tiap informan agar seseorang dapat memecahkan masalahmasalah yang dihadapi. Proses social casework 
merupakan salah satu upaya menyelesaikan masalah yang ada (problem solving).

Menurut Hellen Harris Perlman (1991:1) dalam Irham (2010: 38) menyatakan bahwa :

"social casework adalah suatu proses yang digunakan oleh badan-badan sosial tertentu untuk membantu individu-individu agar dapat memecahkan masalah-masalah yang mereka hadapi di dalam kehidupan sosial mereka secara lebih efektif"

Dalam social casework, terdapat elemenelemen pendukung di dalamnya, yaitu antara lain :

1. Person adalah individu yang datang pada badan-badan tertentu untuk meminta pertolongan.

2. Place adalah lembaga berbadan hukum yang membantu individu dalam menyelesaikan masalah-masalah.

3. Problem adalah masalah yang dipecahkan.

4. Professional adalah tenaga profesional atau tim ahli yang membantu klien memecahkan masalah.

\section{Sistem Dasar Pekerjaan Sosial}

Dalam memberikan pelayanan untuk memecahkan masalah (problem solving) bagi orangtua usia dini dalam memberikan pengasuhan yang baik dan benar terhadap anaknya, sistem dasar pekerjaan sosial berusaha untuk melihat dari berbagai sistem yang berada dalam lingkungan anak dan orangtua yang dapat memberikan pengaruh terhadap pola pengasuhan anak.

Fungsi-fungsi sistem yang ada dalam lingkungan anak digunakan untuk melakukan perubahan-perubahan agar mencapai tujuan yang ingin dicapai.

Pendapat Pincus dan Minahaan yang dikutip dalam Edi Suharto (1997:319-320), membagi sistem dasar pekerjaan sosial kedalam empat jenis, yaitu : a. Sistem Pelaksana Perubahan (Change agent system) : sekelompok orang yang tugasnya memberikan bantuan atas dasar keahlian yang berbeda-beda dan bekerja dengan sistem yang berbeda-beda pula ukurannya.

b. Sistem Klien : Sistem klien merupakan individu, kelompok, keluarga, organisasi atau masyarakat yang meminta bantuan atau pelayanan kepada sistem pelaksana perubahan.

c. Sistem Sasaran : Pihak-pihak yang dapat dijadikan sasaran perubahan, atau dijadikan media yang dapat mempengaruhi proses pencapaian tujuan pertolongan.

d. Sistem Kegiatan : Menunjuk pada orangorang yang bekerjasama dengan pekerja sosial untuk melakukan usaha-usaha perubahan melalui pelaksanaan tugastugas atau program kerja.

Konsepsi mengenai sistem dasar ini menunjukkan bahwa pendekatan pekerjaan sosial bersifat komprehensif dan holistic. Agar proses pertolongan pekerjaan sosial berjalan secara optimal, maka pekerja sosial harus mampu memobilisasi dan mendayagunakan setiap sistem dasar ini secara terintegrasi dan harmonis.

\section{KESIMPULAN}

Pengetahuan remaja perempuan yang rendah mengenai kesehatan reproduksi, dukungan orangtua dan keluarga terhadap pelaksanaan pernikahan usia dini, pergaulan bebas remaja, merupakan faktor perilaku yang menyebabkan terjadinya pernikahan usia dini. Pemerintah melalui pemerintah daerah perlu mensosialisasikan secara merata kepada masyarakat tentang UU Perkawinan, bersama dengan tokoh masyarakat setempat untuk memberi dukungan kepada keluarga dan masyarakat dalam rangka penundaan usia perkawinan agar menekan tingkat pernikahan usia dini di lingkungan masyarakat. Bagi pelayanan kesehatan tingkat desa seperti 
Posyandu (Pos Pelayanan Terpadu) dan sebagainya untuk mengoptimalkan pelaksanaan program berencana, memberi pembinaan kepada remaja tentang kesehatan reproduksi, dan memberi pengarahan yang baik dan benar terkait pola asuh terhadap anak; bagi Tokoh Masyarakat untuk aktif melakukan komunikasi dengan masyarakat tentang konsep keluarga berencana dan mendukung upaya peningkatan pengetahuan masyarakat khususnya remaja tentang kesehatan reproduksi.

\section{DAFTAR PUSTAKA}

Arifin. 1978. Hubungan Timbal Balik Hubungan Agama Pendidikan Agama di Lingkungan Sekolah dan Keluarga. Jakarta : Bulan Bintang.

Soegarda Poerbakawatja, Harahap. 1982. Ensiklopedi Pendidikan. Jakarta : Gunung Agung.

Syamsu, Yusuf. 2000. Psikologi Perkembangan Anak dan Remaja. Bandung : Remaja Rosda Karya.
Wibawa, Budhi. Raharjo, Santoso T. Budiarti S, Meilany. 2010. Dasar-dasar Pekerjaan Sosial. Bandung: Widya Padjadjaran.

Bariroh. 2006. Studi Komparasi Pola Asuh Orangtua (Parenting Style) terhadap Akhlak Siswa Mts Taqwal Ilah. Semarang : IAIN Semarang

Manar, Irham. 2014. Peranan Orangtua dalam Kemandirian Anak Autis Siswa SLB D YPAC Bandung. Jatinangor : Unpad

Uswatun Hasanah, Anas. 2013. Pengaruh Karakteristik Keluarga dan Pola Asuh Oleh Orangtua Usia Dini : Universitas Sumatera Utara

UNICEF, 2005. Early Marriage A Harmful Traditional Practice A Statistical Exploration. The United Nations Children's Fund (UNICEF).

Undang-Undang Republik Indonesia Nomor 1 Tahun 1974 Tentang Perkawinan 